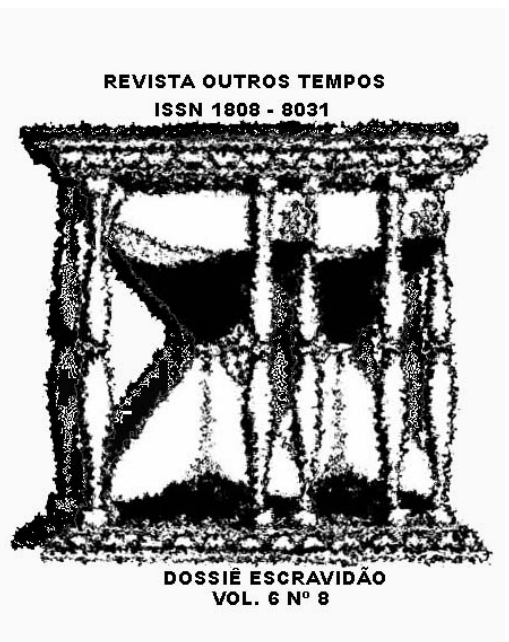

\title{
Revolta escrava
}

O documento é de 12 de maio de 1783, páginas 93, $93 \mathrm{v}$ e 94 do livro número 12 de Registro das Correspondências trocadas entre os governadores do Estado de Maranhão e Piauí e a administração portuguesa, preservado no Arquivo Público do Estado do Maranhão. Escrito pelo governador da época, Antonio de Salles e Noronha, relata o assassinato de um Sargento na Ribeira do Itapecuru, seguido da morte do dito escravo e as providências tomadas pelos administradores na capitania do Maranhão. São interessantes as conjecturas montados pela mesma administração sobre a morte do escravo e as providências a serem tomadas pelos mesmos, receosos de uma possível revolta escrava.

Esta transcrição livre seguiu algumas normas, mas outras foram adaptadas. Várias palavras que estavam abreviadas no texto original foram desenvolvidas para facilitar o entendimento do texto. Palavras unidas no original foram separadas. Além disso, a transcrição é acompanhada por um conjunto de caracteres que significam basicamente mudança de linha (//), os termos entre [] significam observações feitas por mim para identificar mudanças de páginas, palavras corroídas, ilegíveis, ou simplesmente transcritas como no original por mais que não faça sentido (o chamado "sic").

Ms. Reinaldo dos Santos Barroso Jr. Universidade Estadual do Maranhão (UEMA) silesius2001@yahoo.com.br

Conta a S. Magestade pello seu Com//celho ultramarino sobre a morte feita ao Sargento Mor // de [Milícias] [?] Joaquim José por hum seo escravo.

Senhora $=$ Na ribeira do Itapecuru sucedeo matarem // os Escravos do Sagento Mor Joaquim José a este metendo // lhe pelas entranhas huma faca encantoada em hum pão dentro da sua // própria casa; o principal agressor daquela morte e outros que // se supunhão haver concorrido para ella logo forão prezos por se achar // o juiz vereador na dita Ribeira devassando das continua//das mortes que nela fazem os Negros donde tão bem tirou a do dito // sargento mor. Na ocazião em que forão os soldados conduzir // a aquelles escravos prezos [ilegível 1 palavra] para confessarem se ha//vião outros q praticassem concorrido para a mesma morte; o prin//cipal agressor della que já se achava havia dias preso e emperrado [sic] // sem querer ficando lhes algumas feridas dos assoites, nem estas // consentio que lhe fossem curadas de sorte que por gastar vários // dias na viagem chegarão a temer más [ilegível 1 palavra] e alguns [ilegível 1 palavra]// aproximando-se da ilha desta cidade faleceo não se podendo // averiguar se por isso haviam tomado o folgo, como costumão fazer // muitos negros para serem omissidas deles próprios, se pella // falta de sustento que havião muitos dias não queria tomar ou se da ferida // dos assoutes como declarão os cirurgioens que para lhe fa//zerem vistoria forão chamados. Chegado que foi o Escravo a cidade// pello Juiz Vereador andar naquelas diligencias ordenei ao Ouvidor pela// constante da cópia $\mathrm{N}^{\mathrm{o}} 1$ que mandasse proceder a exame no dito negro o// que fes remetendo o auto de corpo de delicto ao 
Juiz Vereador e ordenan//dolhe pello officio cuja copia he a do $\mathrm{N}^{\circ} 2$ procedesse a devassa visto // do dito auto a legitima cauza daquella morte segundo declarão // os cirurgioens no auto de corpo de delicto constante da copia $\mathrm{N}^{\mathrm{o}} 3 . / /$

Recebendo o Juiz Vereador aquelle officio e ditto auto de corpo de delicto e// sabendo os moradores daquella Ribeira que intentava devassar do cazo , lhe// entrarão a requerer e ponderar as funestas conseqüências que infalível // mente se seguirão vindo a saber a escravatura que aquelle respeito // havia o menor procedimento por que ficaria mais absoluta na consi//deração de que não devião ser castigados ainda em cazos tão atrozes // [fl 93v] atrozes como o corrente quando sem isso se achão tão atrevidos, que // continuadamente estão fazendo mortes, ainda aos mesmos feitores que // os governão, por ser o numero da Escravatura grande naquela ribeira // de sorte que há hoje vivem os Senhores reciozos e arriscados. Es//tas reprezentacoens me expoz o juiz vereador pela carta // de copia numero 4 em tempo que veyo a esta cidade o Baxarel Henriques Guilhon// Juiz de Fora que foi na mesma requerer-me e ponderar-me que não // hera convincente fazer o menor movimento a respeito da morte da//quelle escravo por que seria influhir em todos os outros os outros espíritos // para com menor temor continuarem a fazer mortes estando já va//rios senhores resolutos a deixarem suas cazas e virem para a // Cidade por lhes não suceder o mesmo que ao dito sargento mor defunto.

Vendo eu o estado das couzas e desejando que no tempo de meo governo // não sucedão as funestas consequencias que [me forão ponderadas][?] e eu // tenho por infalíveis mandey por carta cuja copia he a de $\mathrm{N} 5^{\circ}$ he // colher a esta secretaria o dito auto de corpo delicto a que tinha man//dado proceder para tudo por na Real Prezença de Vossa Magestade [corroído uma linha] Real Serviço.

He sem duvida que o número da escravatura daquella ribeira he grande e os // brancos que nella assistem muito poucos em comparação dos mesmos // escravos, estes altivos e já tão dezaforados que continuadamente estão fa//zendo mortes sem poder haver castigos, por que logo que fazem os di//lictos se refugião pelas matas dahonde é impossível tirallos e quando // a este respeito se devem procurar os meyos para com castigos subjugar // e trazelos a obediência pâresse[sic] se lhe não deve dar fomento com a menor // demonstração contra os brancos que os haverem de castigar licitamente // ainda em o sucesso presente, em que teve o escravo mencionado ar// rojo de matar o seu próprio senhor dentro da sua mesma caza // indo a isso de propozito com huma faca encantoada em hum pão que// em tão cazo, ainda que de cazo pensado fosse morto de assoutes se // devia disfarçar para não dar ocazião a mayor damno. Com aquella minha determinação, não só o juiz vereador mas tão // bem o Juiz de fora que lhe sucedeo na jurisdição por verem ser acer//tado não seproceder em couza alguma sem Determinalçao de Vossa // Magestade; porem o Ouvidor Geral sem embargo de não pertencer a //[fl 94] sua jurisdição aquella devassa como tão amigo de novi//dades, mal intencionado e sem reparar annada, tem mandado // ao Juiz de Fora vá tirar a dita devassa a que lhe [resiste][?] não só // por reconhecer a falta de jurisdição que tem para o mandar em // semilhante cazo, como por se perssuadir de que o represento // a V. Magestade de quem espera a resolução, pois não padece a adminis//tração da Justiça na pouca demora que para ella possa haver.

Eu me perssuado há vista de não constar ter falescido aquel//le Escravo dos assoutes e se verificar pello mesmo auto de// corpo de delicto que por emperrado não quis mais comer de//pois que foi prezo e nem se deixar curar e ser costume nesta// qualidade de Escravo tomarem o folgo para se matarem assi pro//pio como se prezume dez o de que se trata logo que se vio com//duzido e proximo a Ilha desta cidade, suposta a Reprezentação que //fez o Juiz Vereador, não se dever a este Respeito innovar// couza alguma não obstante o que desejando o milhor acerto// ponho tudo na Real Prezença de Vossa Magestade para que 
determi//ne o que for de seu melhor agrado embenificio destes Povos. Maranham, 12 de Mayo de 1783. D. Antonio de Salles e Noronha. 